\title{
SHOULD FIRMS KEEP A BALANCE BETWEEN STATE AND FOREIGN OWNERSHIP? A PERSPECTIVE ON FINANCIAL CONSTRAINTS AND INVESTMENTS IN VIETNAM
}

\author{
Christopher Gan ${ }^{1}$ \\ D Dao Le Trang \\ $\mathrm{Anh}^{2+}$
}

\author{
${ }^{1,2}$ Faculty of Agribusiness and Commerce, Lincoln University, New Zealand. \\ 'Email: christopher.gan@lincoln.ac.nz Tel: +64 34230227 \\ sEmail:Le.dao@lincolnuni.ac.nz Tel:+64212699906
}

The Check for updates

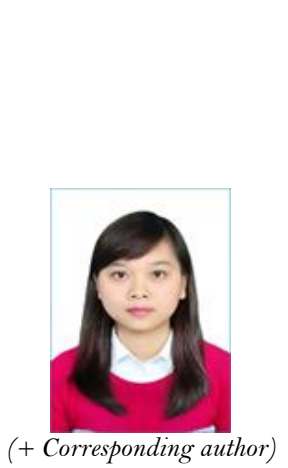

\section{Article History \\ Received: 5 February 2019 Revised: 7 March 2019 \\ Accepted: 12 April 2019 Published: 8 May 2019}

\section{Keywords}

Financial constraints

Foreign ownership

Non-financial firms

State ownership

Investments

Vietnam.

JEL Classification:

Go; G1; G3.

\section{ABSTRACT}

State and foreign ownership are increasing their role in financial management and performance of Vietnamese enterprises in the context of global and regional economic integration. Meanwhile, financial constraints and investments are two essential elements affecting corporate financial success. This study investigates the influences of governmental and foreign ownership on financial constraints and investment decisions of enterprises in Vietnam. Using regression models for panel data of 657 non-financial firms listed in Vietnam stock market, the study reveals that Vietnam listed firms with higher rates of state-owned shares exhibit higher levels of financial constraints. State ownership also restricts firms' investments. On the other hand, foreign ownership helps to reduce the investment - cash flow sensitivity and enhances the firms' investment levels. As a result, the study recommends that Vietnamese firms should try to eliminate the role and percentage of state ownership as well as attract more foreign investors to enhance the financial barrier and increase more promising investment opportunities to boost the firms' financial outcomes.

Contribution/ Originality: This is the first study that attempts to explore the effects of state and foreign ownership on different financial constraint indexes of Vietnamese enterprises. Furthermore, this study contributes to the assessment of the impacts of governmental and foreign ownership on corporates' investment cash flow sensitivity and investment levels in Vietnam.

\section{INTRODUCTION}

Vietnam has actively participated in the economic integration process since the 1990s. In 1995, Vietnam became an official member of the Association of Southeast Asian Nations (ASEAN), a milestone for Vietnam's economic integration and development. Next, Vietnam took part in the Asia-Europe Meeting in 1996 and the AsiaPacific Economic Cooperation in 1998. Vietnam successfully went through the negotiation process to become a World Trade Organization's member in January 2007.

Vietnam and other ASEAN state members officially formed the ASEAN Economic Community (AEC) at the end of 2015. AEC is regarded as a manufacturing and trading hub that is dynamic, resilient and highly integrated into the global economy (ASEAN Secretariat, 2015). One highlighted constituent element of AEC is free movement 
of investments. Following this important development, there are numerous opportunities for regional enterprises and global investors to optimise their profits by raising more funds and diversifying their investment portfolios.

State and foreign ownership are two of the most influential ownership types in Southeast Asian countries including Vietnam (Van Essen et al., 2011; Claessens and Yurtoglu, 2013; Witt and Redding, 2013). Based on the regional and global economic integration, the roles of state and foreign investors have become more and more critical to the success of domestic companies. For instance, Liang et al. (2015) conclude that after the national governance reform, government ownership has a stronger effect on the globalisation process of state-owned nonfinancial Chinese listed companies. Beuselinck et al. (2017) discover that state-owned companies are more stable and lose smaller value than other firms during the recent 2008 global financial crisis. In term of foreign ownership role, Desai and Forbes (2004) and Kolasa et al. (2010) prove that foreign-owned enterprises react better than domestic companies in dealing with the aftermath of the 2008 global financial crisis. State and foreign ownership are becoming more important to companies in global integration, but financial constraints and investment decisions are the two essential elements affecting firms' financial success. Therefore, understanding how state and foreign ownership affect firms' financial constraints and investment decisions will help companies to decide on the appropriate ownership structures that alleviate financial restrictions and to make wise investment decisions.

Although the influences of state and foreign ownership on firms' financial constraints and investment decisions are explored widely for developed markets in previous literature, studies in Vietnam, however, are limited and incomplete. Therefore, this study investigates the effects of government and foreign ownership on different financial constraints indexes of Vietnamese enterprises. The study also investigates the impacts of governmental and foreign ownership on investment-cash flow sensitivity and investment levels of Vietnamese enterprises.

\section{LITERATURE REVIEW}

\subsection{Financial Constraints and Investment Decisions}

Modigliani and Miller (1958) introduce their theorem describing an ideal capital market where corporates' investment decision-making is unrelated to funding options. However, in a realistic world, the existence of information asymmetry (Stiglitz and Weiss, 1981; Greenwald et al., 1984) agency problems (Gertler and Bernanke, 1989), moral hazard issues (Jensen and Meckling, 1976) and transaction costs (Coase, 1937) violate the theorem. As a result, internal and external financing are inconvertible sources of funds, which follow the pecking-order theory introduced by Myers and Majluf (1984). Thus, firms' financial constraints transpire as a normal and well-admitted subsequence in imperfect capital markets.

Corporates' financial constraints are identified by different methods such as investment-cash flow sensitivity models or by formulated indexes.

In terms of models, Meyer and Kuh (1957) publish the first study on investment - cash flows connectivity as a signal of firms' financially constrained condition. However, until 1988, Fazzari, Hubbard and Petersen formally estimate investment - cash flows relationship as a measurement of financial constraints. Fazzari et al. define financial constraints in such a way that if the firms' external financing costs are higher than internal funding costs, a significant influence of cash holdings on investments would exist. Fazzari et al. (1988) categorise 422 American firms into three classes based on their dividend payments and apply the q-theory framework to assess the connectivity between investments and cash flows. The authors conclude that the fewer dividends distributed by the firms due to financial restrictions, the more sensitive investment-cash flow relations those enterprises face.

The sensitivity magnitude between investment level and cash flow is adopted widely to recognise and assess firms' financial constraints, Kaplan and Zingales (1997) oppose Fazzari et al.'s idea and convince that employing the regressed relationship between cash flows and corporate investments as an estimation of financial constraints may lead to misleading results. Kaplan and Zingales reveal that firms sorted in lower financially constrained groups have higher levels of investment-cash flow sensitivities than groups of companies with greater financing 
constraints. Moreover, Kaplan and Zingales generate a U-shaped figure to indicate the investment-cash flow relations, whereas the reverse transpires when the firms are caught in financial distress.

To address the antagonistic conclusions of Fazzari et al. (1988) and Kaplan and Zingales (1997); Cleary et al. (2007) denote that employing different criteria to classify financially constrained firms leads to conflicting results. The authors also obtained a U-shaped relationship between internal fund availability and investments of firms. When not classifying firms into different financial constrained levels, the connection of investment and cash flows truly indicates investment decisions of the firms (Bushman et al., 2007).

Along with the debate on whether the tie-in between investment level and cash flow is an appropriate measurement of financial restrictions, a number of studies have developed modern proxies to evaluate firms' financial constraints. There are currently four indexes of financial constraints including KZ index (designed by Lamont et al. (2001)) WW index (named under Whited and Wu (2006)) SA index (created by Hadlock and Pierce (2010)) and ASCL index (Mulier et al., 2016).

Specifically, the KZ index is created by reapplying the original models and samples of Kaplan and Zingales (1997) and computed as follows:

$$
\begin{aligned}
& (-1.0019) * \frac{\text { Cash flows }}{P P E}+0.2826389 * Q+3.139193 * \frac{\text { Debts }}{\text { Total assets }}+(-39.3678) * \frac{\text { Dividend }}{P P E}+ \\
& (-1.314759) * \frac{\text { Cash }}{P P E}
\end{aligned}
$$

Where PPE represents the Property, Plant and Equipment items on the firm's balance sheet of the previous year; Cash flows are the calculated from net profit plus depreciation; $Q$ stands for Tobin's $Q$ (Tobin, 1969) of the firm; Debts are the long-term debts; Cash is a sum of cash and short-term investments. Firms with greater KZ Index scores are more inclined to endure financial restrictions than the firms with lower KZ Index scores.

Whited and $\mathrm{Wu}$ (2006) construct the WW index that consistently associates with firms' external finance constraints. Their WW index is calculated as follows:

$$
\begin{aligned}
& -0.091 \text { CASHFLOW }_{i}-0.062 \text { DDIV }_{i t}+0.021 \text { DEBT }_{i t}-0.044 \text { SCALES }_{i t}+ \\
& 0.102 \text { INGR }_{i t}-0.035 \text { IRMGR }_{i t}
\end{aligned}
$$

Where: $C A S H F L O W_{\mathrm{i}}$ is the rate of cash flow over total assets; $D D I V_{\text {it }}$ takes a value of one if the firm pays cash dividends and zero otherwise; $D E B T_{i t}$ is percentage of long-term debts in total assets; SCALE it is the natural logarithm of total assets; $I N G R_{i t}$ is sales growth of industry that the firm works in; and FIRMGR is sales growth of individual firm. A large (small) value of WW index indicates a high (low) level of financial restrictions.

Hadlock and Pierce (2010) suggest that a measure of financially-constrained level of a firm must be solely based on that firm's characteristics. Using an ordered logit model based on the detail qualitative information of firms from 1995 to 2004, the authors indicate that the financial constraints of a firm will decrease as the business grows in scale and has a longer operating period. They propose the Scale-Age Index (SA index) as an indicator of financial constraints as follows:

$$
(-0.737 * T A)+\left(0.043 * T A^{2}\right)-(0.040 * L E N G T H)
$$

Where firm scale $(T A)$ is determined by the natural logarithm of the firm's total assets, LENGTH is the amount of time counted since the firm's information first listed in the Compustat system. Generally, firms with high SA index score is likely to be financially constrained.

Recently Mulier et al. (2016) incorporate the financial indicators of KZ index, WW index and SA index in their new financial constraints categorisation called the ASCL index. According to the ASCL index, external funding is dependent on four main factors: age (A), size (S), cash flows (C) and leverage (L). Next, the authors simplify the classification as follows: if the firm is under industry average in one determinant, the firm gains a score of 1. 
Otherwise, the firm gets a score of $\mathrm{O}$. A score of $\mathrm{O}$ in all of the four dimensions indicates a firm is not financially constrained, while a score of 4 implies a fully financial constrained firm. Firms with high scores need to pay more expensive interest rates and face higher chances of bankruptcy.

\subsection{Effects of State and Foreign Ownership on Firms' Financial Constraints and Investment Decisions 2.2.1. Influences of State and Foreign Ownership of Firms' Financial Constraints}

Different types of corporate ownership exhibit different impacts on firms' financial constraints. The linkages between government ownership and financial constraints are controversial among the past literature. Laeven (2002) suggests that firms' financial constraints decrease when firms reduce the percentage of state-owned shares. Consistent with Laeven (2002); Mykhayliv and Zauner (2013;2017) conclude a positive relationship between levels of state ownership and firms' financial constraints. In addition, Lin and Bo (2012) investigate the role of government ownership on firms' financial constraints indicate that state ownership has no contribution in eliminating firms' funding barriers on investments of Chinese firms. On the other hand, Haider et al. (2017) study the relationships between government ownership and firms' financial constraints across 81 countries and demonstrate that state-owned businesses suffer lower levels of financial constraints in general. With similar result to Haider et al. (2017); Yan et al. (2017) state that Chinese private firms bear more internally and externally financing constraints than state-owned enterprises. For foreign ownership, Mertzanis (2017) identifies a negative binding between foreign-owned shares and financing restrictions of firms in developing countries. Furthermore, the author concludes that foreign ownership is a proper predictor of firms' financial constraints in developing economies.

\subsubsection{Influences of State and Foreign Ownership on Corporate Investments}

Ownership structure also plays a crucial role in corporate investment behaviours (OECD, 1999; Chen et al., 2017).

Regarding the impacts of governmental ownership on firms' investments, Mykhayliv and Zauner (2013;2017) demonstrate a significantly negative influence of state ownership on Ukrainian firms' investments. Chen et al. (2016) conclude that government ownership creates more severe under-investment conditions. He and Kyaw (2017) also find a negative impact of governmental ownership on corporate under-investment problems.

The association between foreign ownership and investments are discussed in both developed and developing markets. Koo and Maeng (2006) discover that the co-movement of investment and cash flow is lower for Korean firms with higher level of foreign-owned shares. Recently, Chen et al. (2017) use 506 privatised firms in 64 countries to investigate the association between corporates' ownership structures and firms' investment behaviour. The authors reveal that foreign ownership has an impact on firms' investment - Tobin's q sensitivity as well as increases the firms' level of investment efficiency.

However, studies that investigate the effects of state and foreign ownership on Vietnam enterprises' financial constraints and investment decisions are limited and incomplete. O'Toole and Newman (2012) reveal that financial constraints decrease in Vietnam firms in the private sector but increase in state-owned enterprises. Tran and Le (2017) confirm that non-government enterprises in Vietnam tend to react to investment opportunities better than government enterprises when they deal with financial difficulties.

The considerable gap in the literature, together with the robust integration process in Vietnam that enhances the financial conditions and business performance of Vietnamese firms, motivates this study. 


\section{RESEARCH HYPOTHESES}

This study evaluates the impacts of state and foreign ownership on firms' financial constraints and investments in Vietnam. Based on the findings of prior researches, the study generates four hypotheses for Vietnam firms as follows:

Hypothesis H1: State ownership has positive and significant impacts on Vietnam firms' financial constraints.

Hypothesis H2: State ownership has negative and significant impacts on Vietnam firms' investment levels.

Hypothesis H3: Foreign ownership has negative and significant influences on Vietnam firms' financial constraints. Hypothesis H4: Foreign ownership has positive and significant effects on Vietnam firms' investment levels.

\section{RESEARCH METHODOLOGY}

\subsection{Definition of Terms \\ 4.1.1. State Ownership and Foreign Ownership:}

In this study, state and foreign ownership are measured by the percentage of firms' shares held by the government and foreign investors, respectively.

The study employs a dummy variable for state and foreign ownership as D_STATE and D_FOREIGN, respectively. According to La Porta et al. (1999) corporate ownership is categorised based on the share-holding amount. The authors conduct comprehensive global research on ownerships to identify the firms' biggest shareholders with at least $20 \%$ of shares. Following La Porta et al., D_STATE variable in this study takes a value of 1 if the enterprise has more than $20 \%$ of shares owned by the state, and o otherwise. For D_FOREIGN variable, due to the restriction of shares held by foreigners in Vietnam before 2014 which made the percentage of foreign owned-share relatively low, the variable takes a value of 1 if the firm has more than $10 \%$ of shares owned by foreign investors, and o otherwise.

\subsubsection{Financial Constraints Indexes:}

This study applies three different proxies of financial constraints including KZ index (designed by Lamont et al. (2001)) WW index (named after Whited and Wu (2006)) and SA index (created by Hadlock and Pierce (2010)) to measure constrained levels of the firms. These three proxies are presented in Equations 1, 2, and 3, respectively. The three indexes follow different criteria (such as availability of an internal source of funds - KZ index; external financial constraints - WW index; corporate characteristics including firm size and firm age - SA index) to determine the factors that reflect the financial constrained condition of the firms. The three indexes provide a comprehensive view of financially constrained conditions of the firms.

\subsubsection{Investment Decisions:}

Following Lin and Bo (2012) this study adopts investment - cash flow sensitivity to estimate both financial constraints (Fazzari et al., 1988) and investment decisions of the firms (Bushman et al., 2007).

\subsection{Empirical Models}

The study employs Fixed Effects (FE) and Random Effects (RE) regression models for panel data to evaluate the impact of state and foreign ownership on firms' financial constraints and investment decisions. According to Bollen and Brand (2010) FE and RE are commonly used for panel data regression models because of their advantage of controlling omitted variables that are constant over time. However, both FE and RE methods have advantages and disadvantages (Clark and Linzer, 2015). While FE model will generate unbiased estimates for the coefficients of the independent variables, these estimates may subject to sample variations. RE models, on the other hand, will create bias estimates of explanatory variables' coefficients but may limit the variance among different samples. Therefore, this study adopts both FE and RE methods in the estimation. 
- Regression models to test the influences of state and foreign ownership on firms' financial constraints indexes: Based on Lin and Bo (2012) the empirical models are:

Model 1 using KZ index as the dependent variable:

$$
\begin{aligned}
K Z_{i t} & =\beta_{1 a}+\beta_{1 b} \text { STATE }_{i t}+\beta_{1 e} \text { FOREIGN }_{i t}+\beta_{1 d} \text { Size }_{i t}+\beta_{1 \mathrm{e}} \text { Age }_{i t}+\epsilon_{i t} \\
K Z_{i t} & =\beta_{1 g}+\beta_{1 k} D_{-} \text {STATE }_{i t}+\beta_{1 k} D_{-} \text {FOREIGN }_{i t}+\beta_{1 b} \text { Size }_{i t}+\beta_{1 m} \text { Age }_{i t}+\epsilon_{i t}(\mathrm{M} 1 \mathrm{~b})
\end{aligned}
$$

Model 2 using WW index as the dependent variable:

$$
\begin{aligned}
& W W_{i t}=\beta_{2 a}+\beta_{2 b} \text { STATE }_{i t}+\beta_{2 c} \text { FOREIGN }_{i t}+\beta_{2 d} \text { Age } \\
& \text { it }
\end{aligned}
$$

Model 3 using SA index as the dependent variable:

$$
\begin{aligned}
& \text { SA }_{i t}=\beta_{3 a}+\beta_{3 b} \text { STATE }_{i t}+\beta_{3 c} \text { FOREIGN }_{i t}+\beta_{3 d} \text { SalesGR }_{i t}+\beta_{3 e} \text { DDiv }_{i t}+\beta_{3 f} \text { Lev }_{i t}+ \\
& \beta_{3 g} \text { Cash }_{i t}+\epsilon_{i t} \\
& \text { SA }_{i t}=\beta_{3 h}+\beta_{3 k} D_{-} \text {STATE }_{i t}+\beta_{3 i} D_{-} \text {FOREIGN }_{i t}+\beta_{3 m} \text { SalesGR }_{i t}+\beta_{3 n} \text { DDiv }_{i t}+\beta_{3 p} \text { Lev }_{i t}+ \\
& \beta_{3 q} \text { Cash }_{i t}+\epsilon_{i t}
\end{aligned}
$$

Table 1 defines the variables used in models 1, 2, and 3:

Table-1. Definition of variables used in model 1, 2 and 3 equations.

\begin{tabular}{l|l}
\hline $\begin{array}{l}\text { Model } \\
\text { variables }\end{array}$ & Definition \\
\hline$K Z$ & score of KZ index of firm \\
\hline$W W$ & score of WW index of firm \\
\hline$S A$ & score of SA index of firm \\
\hline STATE & percentage of state-owned shares of the firm \\
\hline FOREIGN & percentage of foreign-owned shares of the firm \\
\hline$D \_S T A T E$ & a dummy variable, $=1$ if the firm has more than $20 \%$ of state ownership, O otherwise \\
\hline$D \_F O R E I G N$ & dummy variable, $=1$ if the firm has more than $10 \%$ of foreign ownership, O otherwise \\
\hline Size & firm scale, estimated by the natural logarithm of the firm's total assets of the firm \\
\hline Age & the length the firms are listed on the stock markets \\
\hline SalesGR & firms' growth rate of sales of the firm \\
\hline DDiv & dummy variable of the firm, = 1 if the firm pays dividend, o otherwise \\
\hline Lev & long-term debts over total assets of the firm \\
\hline Cash & cash over total assets of the firm \\
\hline$\varepsilon$ & error term \\
\hline Source: Authors' Development of Model Variables.
\end{tabular}

- Regression models to test the impacts of ownership structure on corporates' investments-cash flow sensitivity

This study adopts and modifies the models of Lin and Bo (2012) to investigate the influence of state and foreign ownership on the investment-cash flow relationship of the firms.

Model 4:

$$
\begin{aligned}
& \left(\frac{\text { Inv }}{K}\right)_{i t}=\gamma_{0}+\gamma_{1}\left(\frac{\text { Inv }}{K}\right)_{i, t-1}+\gamma_{2} Q_{i, t-1}+\gamma_{3} \text { SalesGR }_{i, t-1}+\gamma_{4}\left(\frac{C F}{K}\right)_{i, t-1}+\gamma_{5}\left(\frac{C F}{K}\right)_{i, t-1} * \\
& \text { STATE }_{i, t-1}+\gamma_{6}\left(\frac{C F}{K}\right)_{i, t-1} * \text { FOREIGN }_{i, t-1}+\gamma_{7}\left(\frac{\text { Debts }}{K}\right)_{i, t-1}^{2}+\gamma_{8}\left(\frac{\Delta W C}{K}\right)_{i, t-1}^{2}+\gamma_{9} \text { STATE }_{i, t-1}+ \\
& \gamma_{10} \text { FOREIGN }_{i, t-1}+\gamma_{11} \text { LNTA }_{i, t-1}+\epsilon_{i t}
\end{aligned}
$$




$$
\begin{aligned}
& \left(\frac{I n v}{K}\right)_{i t}=\gamma_{12}+\gamma_{13}\left(\frac{I n v}{K}\right)_{i, t-1}+\gamma_{14} Q_{i, t-1}+\gamma_{15} \text { SalesGR }_{i, t-1}+\gamma_{16}\left(\frac{C F}{K}\right)_{i, t-1}+\gamma_{17}\left(\frac{C F}{K}\right)_{i, t-1} * \\
& \text { D_STATE } i_{i, t-1}+\gamma_{18}\left(\frac{C F}{K}\right)_{i, t-1} * D_{-} \text {FOREIGN } N_{i, t-1}+\gamma_{19}\left(\frac{D e b t s}{K}\right)_{i, t-1}^{2}+\gamma_{20}\left(\frac{\Delta W C}{K}\right)_{i, t-1}^{2}+ \\
& \gamma_{21} D_{-} \text {STATE } i_{i, t-1}+\gamma_{22} D_{-} \text {FOREIGN } i_{i, t-1}+\gamma_{23} \text { LNTA }_{i, t-1}+\epsilon_{i t}
\end{aligned}
$$

Table 2 defines the variables used in Model 4.

Table-2. Definitions of variables used in Model 4 equations.

\begin{tabular}{l|l}
\hline $\begin{array}{l}\text { Model } \\
\text { variables }\end{array}$ & Definition \\
\hline Inv & $\begin{array}{l}\text { investment of firm } \rightarrow \text { equals the difference between the fixed assets of current and previous } \\
\text { year adding depreciation }\end{array}$ \\
\hline$K$ & capital stock $\rightarrow$ equals the total assets of the firm \\
\hline$Q$ & Tobin's Q of firm $\rightarrow$ equals the rate of total market value over total assets \\
\hline$S a l e s G R$ & annual growth rate of firms' sales \\
\hline$C F$ & CF or cash flow is the net profit plus depreciation \\
\hline Debts & total of corporate debts \\
\hline$\Delta W C$ & changes in working capital of the firm \\
\hline$S T A T E$ & \% of state-owned shares of the firm \\
\hline$F O R E I G N$ & $\%$ of foreign-owned shares of the firm \\
\hline$D \_S T A T E$ & dummy variable, = 1 if the firm has more than 20\% of state ownership, o otherwise \\
\hline$D \_F O R E I G N$ & dummy variable, = 1 if the firm has more than 10\% of foreign ownership, o otherwise \\
\hline$L N T A$ & firm size $\rightarrow$ equals the logarithm of total assets \\
\hline$\varepsilon$ & error term \\
\hline Source: Authors' Development of Model variables.
\end{tabular}

\subsection{Data}

This study uses annual financial and ownership data of 657 non-financial listed firms in Vietnam stock exchanges: Ho Chi Minh stock exchange and Hanoi stock exchange. Financial firms are excluded from our study because the normally high levels of debts in financial firms are likely to signal financial distress in non-financial firms (Fama and French, 1992) thus investigating both financial and non-financial firms may generate misleading results.

The data covers a ten-year period from 2007 to 2016. A significant development of ASEAN in 2007 is the commitment of ten ASEAN states to establish the ASEAN Community by 2015. Furthermore, in 2007, ASEAN leaders collectively agreed on AEC Blue Print - a comprehensive master plan to achieve the complete establishment of ASEAN Economic Community in 2015 (ASEAN Secretariat, 2015). Thus, 2007 is chosen as the starting year of the study period and 2016, one year after the official establishment of AEC, as the ending year of the study period. Financial data are extracted from Bloomberg and SPEEDA's database. Ownership data are obtained from the firms' annual reports.

\section{EMPIRICAL RESULTS}

\subsection{Descriptive Statistics}

Table 3 shows the descriptive statistics of Vietnam non-financial listed firms' characteristics. 
Table-3. Descriptive statistics of Vietnam non-financial listed firms characteristics.

\begin{tabular}{l|c|c|c|c|c|c}
\hline $\begin{array}{c}\text { Model } \\
\text { variables }\end{array}$ & Mean & Median & Maxi & Min & Std. Dev. & Jarque-Bera Prob. \\
\hline KZ & -22.97 & -1.95 & 25.41 & -10957.7 & 238.73 & 0.00 \\
\hline WW & -1.51 & -0.55 & 3.49 & -855.60 & 17.08 & 0.00 \\
\hline SA & -1.97 & -2.02 & 0.25 & -3.59 & 0.68 & 0.00 \\
\hline INV & 0.04 & 0.02 & 0.75 & 0.00 & 0.10 & 0.00 \\
\hline STATE & 0.28 & 0.27 & 1.00 & 0.00 & 0.25 & 0.00 \\
\hline D_STATE & 0.54 & 1.00 & 1.00 & 0.00 & 0.50 & 0.00 \\
\hline FOREIGN & 0.11 & 0.02 & 1.00 & 0.00 & 0.84 & 0.00 \\
\hline D_FOREIGN & 0.27 & 0.00 & 1.00 & 0.00 & 0.44 & 0.00 \\
\hline AGE & 3.93 & 4.00 & 16.00 & 0.00 & 3.10 & 0.00 \\
\hline CASH & 0.14 & 0.08 & 0.94 & 0.00 & 0.14 & 0.00 \\
\hline CF & 0.10 & 0.08 & 0.82 & -0.61 & 0.09 & 0.00 \\
\hline DEBTS & 0.50 & 0.53 & 0.97 & 0.00 & 0.22 & 0.00 \\
\hline LNTA & 3.16 & 3.10 & 8.36 & -0.44 & 1.42 & 0.00 \\
\hline SALESGR & 0.38 & 0.11 & 244.45 & -0.99 & 4.88 & 0.00 \\
\hline Q & 0.52 & 0.34 & 9.34 & 0.00 & 0.62 & 0.00 \\
\hline
\end{tabular}

Table 3 shows the average state-owned (27.6\%) and foreign-owned (10.6\%) shares of the 657 non-financial firms listed in Vietnam stock market from 2007 to 2016. The average listed years of non-financial firms on Vietnam stock market are four years. The mean of firm leverage for the 657 non-financial firms is 0.5; thus the debt over equity ratio is 1 . The mean $\mathrm{CASH}$ (cash over total assets) and CF (cashflow over total assets) are 0.14 and 0.1, respectively.

Table 3 also shows the results of the Jarque-Bera test, indicating that the models' variables are not normally distributed.

\subsection{Empirical Results}

\subsubsection{Model 1: KZ as the Dependent Variable (KZ Index Scores)}

Table 4 reports the regression results of Model 1 which tests the effects of state and foreign ownership on firms' KZ financial constraints index score using the FE and RE methods.

Table-4. Regression Results of Model 1 (Equations M1a and M1b).

\begin{tabular}{c|c|c|c|c|c}
\hline \multicolumn{3}{c|}{ Equation (M1a) } & \multicolumn{3}{c}{ Equation (M1b) } \\
\hline Variables & FE & RE & Variables & FE & RE \\
\hline C & -23.879 & $-62.963^{* * *}$ & C & -9.209 & $-45.520^{* * *}$ \\
\hline STATE & 6.745 & 17.335 & D_STATE & -16.089 & -5.673 \\
\hline FOREIGN & 2.013 & 0.825 & D_FOREIGN & $16.879^{*}$ & 2.278 \\
\hline SIZE & -2.877 & $7.649^{* *}$ & SIZE & -5.969 & 4.840 \\
\hline AGE & 1.985 & $2.288^{*}$ & AGE & $2.255^{*}$ & $2.094^{* *}$ \\
\hline
\end{tabular}

Equation (M1a) shows no significant relationship between Vietnam non-financial listed firms' state or foreign ownership variables and $\mathrm{KZ}$ index in both $\mathrm{FE}$ and $\mathrm{RE}$ estimations. The result also shows the relationship between D_FOREIGN variable and KZ index is significant at 10\% level in FE estimation, while the effect of D_STATE on $\mathrm{KZ}$ index is insignificant in both $\mathrm{FE}$ and $\mathrm{RE}$ estimations.

\subsubsection{Model 2: $W W$ as the Dependent Variable (WW Index Scores)}

Table 5 reports the regression results of Model 2 which tests the effects of ownership factors on firms' WW index scores. 
Equation (M2a) shows that STATE variable is positive and significant at 5\% level on firms' WW index in RE estimation. Similarly, D_STATE is significant and positively related to WW index in RE estimation, while D_FOREIGN affects WW index positively in the FE estimation.

Table-5. Regression Results of Model 2 (Equations M2a and M2b).

\begin{tabular}{c|c|c|c|c|c}
\hline \multicolumn{4}{c|}{ Equation (M2a) } & \multicolumn{3}{c}{ Equation (M2b) } \\
\hline Variables & FE & RE & Variables & FE & RE \\
\hline C & -1.071 & $-2.380^{* * *}$ & C & $-2.689^{* * *}$ & $-3.005^{* * *}$ \\
\hline STATE & -1.426 & $2.034^{* *}$ & D_STATE & 0.878 & $1.497^{* * *}$ \\
\hline FOREIGN & 0.168 & 0.059 & D_FOREIGN & $2.228^{* * *}$ & 0.606 \\
\hline AGE & 0.012 & 0.107 & AGE & -0.011 & 0.123 \\
\hline
\end{tabular}

\subsubsection{Model 3: $S A$ as the Dependent Variable (SA Index Scores)}

Table 6 shows the regression results of Model 3, validating the contradictory influences of state and foreign ownership on SA index.

Table-6. Regression Results of Model 3 (Equations M3a and M3b).

\begin{tabular}{|c|c|c|c|c|c|}
\hline \multicolumn{3}{|c|}{ Equation (M3a) } & \multicolumn{3}{|c|}{ Equation (Msb) } \\
\hline Variables & $\mathbf{F E}$ & $\mathbf{R E}$ & Variables & FE & $\mathbf{R E}$ \\
\hline $\mathrm{C}$ & $-2.210^{* * * *}$ & $-2.089 * * *$ & $\mathrm{C}$ & $-2.073^{*} * *$ & $-1.980 * * *$ \\
\hline STATE & $0.450^{* * * *}$ & $0.358 * * *$ & D_STATE & $0.090 * * *$ & $0.081 * * *$ \\
\hline FOREIGN & -0.001 & -0.003 & D_FOREIGN & $-0.111^{* * *}$ & $-0.125^{* * * *}$ \\
\hline SALESGR & 0.0000125 & 0.0000119 & SALESGR & $0.002 * * *$ & $0.002 * * *$ \\
\hline DDIV & $0.208^{* * *}$ & $0.210^{* * * *}$ & DDIV & $0.191^{* * *}$ & $0.189^{* * *} *$ \\
\hline LEV & $-0.546^{* * * *}$ & $-0.612^{* * *}$ & LEV & $-0.419 * * *$ & $-0.483 * * *$ \\
\hline $\mathrm{CASH}$ & 0.015 & 0.013 & $\mathrm{CASH}$ & -0.008031 & 0.000711 \\
\hline
\end{tabular}

Table 6 suggests that both STATE and D_STATE variable are positive and significant at 1\% level with firms' SA index in both estimation methods. In contrast, D_FOREIGN variable is negative and significantly related to firms' $\mathrm{SA}$ index at $1 \%$ level in both $\mathrm{FE}$ and RE estimations.

\subsubsection{Model 4: Inv as the Dependent Variable (Investment Rates)}

Table 7 reports the regression results of Model 4 (equations M4a and M4b).

Table 7 shows that Vietnamese non-financial listed firms are financially constrained based on the positive and significant connection between investment levels and cash flows in all models under the FE and RE estimations.

The results also show the role of state ownership on firms' investment-cashflow sensitivity and investment decisions. Specifically, both STATE and D_STATE variables exhibit positive impacts at 1\% level of significance on the investment-cashflow sensitivity of firms in RE estimation. Also, STATE and D_STATE are negative and significant at $1 \%$ level on corporates' investment levels in RE estimations.

On the contrary, the result shows a significant and negative effect of D_FOREIGN on the magnitude of investments - cashflow sensitivities of Vietnamese non-financial listed firms in RE estimation. Regarding the impacts on investments, the result shows that foreign ownership is positive and significantly related to firms' investment levels in both $\mathrm{FE}$ and RE estimations. 
Table-7. Regression Results of Model 4 (Equations M4a and M4b).

\begin{tabular}{|c|c|c|c|c|c|}
\hline \multicolumn{3}{|c|}{ Equation (4a) } & \multicolumn{3}{|c|}{ Equation (4b) } \\
\hline Variables & FE & $\mathbf{R E}$ & Variables & FE & RE \\
\hline $\mathrm{C}$ & $0.142^{* * * *}$ & $0.011^{*} * *$ & $\mathrm{C}$ & $0.131^{* * * * *}$ & 0.007 \\
\hline$(\ln v)$ & -0.022 & $0.124 * * * *$ & $(\ln v)$ & -0.025 & $0.117 * * *$ \\
\hline$C_{2} C_{2} t-1$ & & & & & \\
\hline$(C F)$ & $0.081 * *$ & $0.183^{*} * *$ & $(C F)$ & $0.132^{* * * *}$ & $0.213 * * *$ \\
\hline$(K)_{i, t-1}$ & & & $(K)_{i, t-1}$ & & \\
\hline$S T A T E_{i, t-1}$ & $-0.047^{*}$ & $\begin{array}{c}- \\
0.033^{*} * * * \\
\end{array}$ & D_STATE $\left.E_{i, t-1}\right)$ & -0.008 & $-0.014 * * * *$ \\
\hline FOREIGN $N_{i, t-1}$ & 0.001 & -0.0003 & D_FOREIGN $N_{i_{z} t-1}$ & $0.011 *$ & 0.007 \\
\hline$\left(\frac{C F}{K}\right)_{i_{i} t-1} * S T A T E_{i_{2} t-1}$ & 0.152 & $0.226 * * *$ & $\left(\frac{C F}{K}\right)_{i, t-1} * D_{-} S T A T E_{i, t-1}$ & 0.04 & $0.091^{* * * *}$ \\
\hline$\left(\frac{C F}{K}\right)_{i, t-1} *$ FOREIGN $N_{i, t-1}$ & -0.015 & -0.019 & $\left(\frac{C F}{K}\right)_{i, t-1} * D_{-}$FOREIGN $N_{i, t-1}$ & -0.058 & $-0.072^{* *}$ \\
\hline$Q_{i_{z} t-1}$ & -0.004 & $\begin{array}{c}- \\
0.009 * * * * \\
\end{array}$ & $Q_{i_{2} t-1}$ & -0.001 & $-0.007 * *$ \\
\hline Sales $G R_{i_{i} t-1}$ & -0.0005 & -0.0001 & Sales $G R_{i_{s} t-1}$ & -0.0002 & 0.00005 \\
\hline$(\text { Debts })^{2}$ & -0.09 & 0.008 & $(\text { Debts })^{2}$ & $-0.063 * * *$ & 0.011 \\
\hline$\left(\frac{K}{K}\right)_{i, t-1}$ & & & $(K)_{i, t-1}$ & & \\
\hline$\left(\frac{\Delta W C}{}\right)^{2}$ & 0.064 & 0.068 & $(\Delta W C)^{2}$ & $0.096 * * *$ & $0.077 * * * *$ \\
\hline$(K)_{i, t-1}$ & & & $(\bar{K})_{i_{i} t-1}$ & & \\
\hline$L N T A_{i, t-1}$ & $\begin{array}{c}- \\
0.023^{*} * *\end{array}$ & $0.003 * *$ & $\operatorname{LNT} A_{i_{i} t-1}$ & $-0.028 * * *$ & $0.002 * *$ \\
\hline
\end{tabular}

Table 8 summarises the regression models results with $\mathrm{FE} / \mathrm{RE}$ methods on the influences of state and foreign ownership on financial constraints and investments of non-financial listed firms in Vietnam.

Table-8. Summary of regression results of Model 1, 2, 3 and 4.

\begin{tabular}{|c|c|c|c|}
\hline Model & Dependent variables & Impacts of state ownership & Impacts of foreign ownership \\
\hline 1 & KZ index & & $\begin{array}{c}+ \\
(\text { D_FOREIGN: } \\
\text { FE method })\end{array}$ \\
\hline 2 & WW index & $\begin{array}{c}+ \\
\text { (STATE } \Xi^{2} \text { D_STATE: } \\
\text { RE method) }\end{array}$ & $\begin{array}{c}+ \\
\left(D_{-} F O R E I G N:\right. \\
F E \text { method })\end{array}$ \\
\hline 3 & $\mathrm{SA}$ index & $\begin{array}{c}+ \\
(S T A T E \text { E D_STATE: } \\
\text { RE \& FE method) }\end{array}$ & $\begin{array}{c}- \\
\left(D \_F O R E I G N:\right. \\
F E \text { ERRE method) }\end{array}$ \\
\hline \multirow[t]{2}{*}{4} & $\begin{array}{c}\text { Investment-cashflow } \\
\text { sensitivity }\end{array}$ & $\begin{array}{c}+ \\
\text { (STATE Eं D_STATE: } \\
\text { RE method) }\end{array}$ & $\begin{array}{c}- \\
(\text { D_FOREIGN: } \\
\text { RE method) }\end{array}$ \\
\hline & Investment rate & $\begin{array}{c}- \\
\text { (STATE: FE E RE method } \\
\text { D_STATE: RE method) }\end{array}$ & $\begin{array}{c}+ \\
\left(D \_F O R E I G N:\right. \\
\text { FE method) }\end{array}$ \\
\hline
\end{tabular}

In general, state ownership consistently exhibits positive impacts on different indexes and measurement of firms' financial constraints. These findings support hypothesis H1 which states that state ownership positively affects Vietnam firms' financial constraints. Regarding the firms' level of investments, state ownership is negatively 
related to firms' investment rates. The result supports hypothesis H2 that state ownership decreases Vietnam firms' investment levels. Foreign ownership, on the other hand, exhibits contradictory influences on different financial constraints indexes (positively affects for $\mathrm{KZ}$ and WW index but negatively affects for SA index). Regarding the financial constraint measurement as investment - cash flow sensitivity, the impact of foreign ownership is negative and significant. This result, therefore, supports hypothesis H3. Similarly, foreign ownership positively affects Vietnam non-financial listed firms' investment rates, thus supports hypothesis H4.

\section{CONCLUSIONS AND DISCUSSIONS}

Ownership structure is considered an important factor that affects firms' financial restriction and investment decisions. In Vietnam, state and foreign ownership are increasing their roles in the firm's financial conditions and management. Based on the $\mathrm{FE}$ and RE regression models for panel data of 657 non-financial companies listed in Vietnam stock markets, the study investigates the influences of government and foreign ownership on corporates' financial constraints and investments in Vietnam. The following conclusions are derived from the empirical results:

(i) Vietnamese non-financial listed firms are financially constrained based on the significant co-movement of corporates' investment and cash flow rates inside the firms see Table 7. This conclusion is similar to Tran and Le (2017) research finding who acknowledge the existence of financial constraints in Vietnamese nonfinancial listed firms.

(ii) State ownership has homogenous effects on various financial constraint measurements see Tables 5, 6, and 7 . More specifically, higher levels of state-owned shares in the Vietnamese non-financial listed firms bring about higher scores of the KZ index, WW index, SA index as well as larger magnitude of investment - cash flow sensitivity. That is, the larger the amount of state-owned shares the firms have, the higher the level of financial constraint the firms endure. The results are similar to findings of Laeven (2002); O'Toole and Newman (2012) and Mykhayliv and Zauner (2013;2017) which demonstrate the co-movements between the firms' levels of state ownership and magnitude of financial constraints.

(iii) Foreign ownership shows dissimilar impacts on different financial constrained indexes (KZ index, WW index, and SA index). These disagreements could be explained by the different components and perspectives of the three financial constraint indexes (KZ index and WW index reflect internal and external sources of funds, and SA index represents for firms' characteristics) that bring about inconsistent results

(iv) Regarding the co-movement between investments and cash flow as a measurement of financial constraints, the study reveals that foreign ownership reduces the investment - cash flow sensitivity, thus diminishing the financially constrained levels of Vietnamese non-financial listed firms. This finding is consistent with Mertzanis (2017) study which suggests a significantly negative relationship between foreign-owned shares and financial restrictions of firms in developing countries.

(v) Finally, state and foreign ownership exhibit contradictory relationships in Vietnamese non-financial listed firms' investments see Table 7. While increasing the level of state ownership results in lower levels of firms' investments, raising the amount of foreign ownership leads to higher investment levels in non-financial listed firms in Vietnam. This result is similar to the conclusion of Chen et al. (2017) which states that specific corporate ownerships affect firms' investment behaviours differently. The empirical finding of the state ownership is also similar to Mykhayliv and Zauner (2013;2017); Chen et al. (2016) and He and Kyaw (2017) who assert the reverse relationship between state ownership and firms' investment level.

\section{RECOMMENDATIONS FOR VIETNAMESE NON-FINANCIAL FIRMS}

Since Vietnam non-financial listed firms are financially constrained, reducing the level of financial restrictions are necessary to the firms' financial development and growth. Based on the co-movements of state ownership levels and firms' financial constraints, our result suggests eliminating the role and percentage of state ownership in 
corporate ownership structure in Vietnam. Specifically, for firms in areas where Vietnam government dominates, the firms should decrease the state-owned shares to $50.1 \%$ of charter capital. With this ratio, the government still has the right to govern the operation of enterprises. For other enterprises, the percentage of state ownership should be reduced as much as possible. In fact, with the reduction of state-owned shares, the financial constraint measurements (KZ index, WW index, SA index and investment - cash flow sensitivity) could be effectively decreased. Besides, loosening state ownership also increases the investment level of the businesses, which results in higher profitability and prosperity for firms in the future. Regarding the impacts of foreign ownership on firms' financial constraints and investment decisions, while the results on different financial constraint indexes are unclear, the negative effects on firm's investment - cash flow sensitivity and positive effects on corporate investments are confirmed. Therefore, Vietnamese non-financial firms should try to attract more foreign investors to enhance the financial barrier as well as to increase more investment opportunities to boost the firms' financial outcomes. Particularly, in the context of regional and global economic integration, Vietnam firms must have better skills to connect with foreign enterprises as well as improve their management and operation to meet the requirements of foreign investors.

Funding: This study received no specific financial support.

Competing Interests: The authors declare that they have no competing interests.

Contributors/Acknowledgement: Both authors contributed equally to the conception and design of the study.

\section{REFERENCES}

ASEAN Secretariat, 2015. A blue print for growth. ASEAN economic community 2015: Progress and key achievements 1 (1): 130. Association of Southeast Asian Nations. Jakarta, Indonesia. Available at: www. asean. org/storage/images/2015/November/aec-page/AEC-2015-Progress-and-Key-Achievements. pdf.(2015b). Available from http://asean.org/?static_post=asean-economic-community-2015-progress-and-key-achievements-2.

Beuselinck, C., L. Cao, M. Deloof and X. Xia, 2017. The value of government ownership during the global financial crisis. Journal of Corporate Finance, 42(C): 481-493.Available at: https://doi.org/10.1016/j.jcorpfin.2015.05.002.

Bollen, K.A. and J.E. Brand, 2010. A general panel model with random and fixed effects: A structural equations approach. Social Forces, 89(1): 1-34.Available at: https://doi.org/10.1353/sof.2010.0072.

Bushman, R.M., A.J. Smith and X.F. Zhang, 2007. Investment-cash flow sensitivities are really investment-investment sensitivities. Working paper, University of North Carolina, USA. Available from http://dx.doi.org/10.2139/ssrn.842085.

Chen, R., S. El Ghoul, O. Guedhami and H. Wang, 2017. Do state and foreign ownership affect investment efficiency? Evidence from privatizations. Journal of Corporate Finance, 42(C): 408-421.Available at: https://doi.org/10.1016/j.jcorpfin.2014.09.001.

Chen, X., Y. Sun and X. Xu, 2016. Free cash flow, over-investment and corporate governance in China. Pacific-Basin Finance Journal, 37(C): 81-103.Available at: https://doi.org/10.1016/j.pacfin.2015.06.003.

Claessens, S. and B. Yurtoglu, 2013. Corporate governance in emerging markets: A survey. Emerging Markets Review, 15(C): 133.Available at: https://doi.org/10.1016/j.ememar.2012.03.002.

Clark, T.S. and D.A. Linzer, 2015. Should I use fixed or random effects? Political Science Research and Methods, 3(2): 399408.Available at: https://doi.org/10.1017/psrm.2014.32.

Cleary, S., P. Povel and M. Raith, 2007. The U-shaped investment curve: Theory and evidence. Journal of Financial and Quantitative Analysis, 42(1): 1-39.Available at: https://doi.org/10.1017/s0022109000002179.

Coase, R.H., 1937. The nature of the firm. Economica, 4(16): 386-405.

Desai, M. and K. Forbes, 2004. Financial constraints and growth: Multinational and local firm responses to currency crises. NBER Working Paper Series, No.10545. 
Fama, E.F. and K.R. French, 1992. The cross-section of expected stock returns. The Journal of Finance, 47(2): 427-465.

Fazzari, S.R., G. Hubbard and B. Petersen, 1988. Finance constraints and corporate investment. Brookings Paper on Economic Activity, 1(1): 141-195.

Gertler, M. and B. Bernanke, 1989. Agency costs, net worth and business fluctuations. American Economic Review, 79(1): 14-31.

Greenwald, B.C., J. Stiglitz and A. Weiss, 1984. Informational imperfections in the capital market and macro-economic fluctuations (No. 1335). National Bureau of Economic Research, Inc.

Hadlock, C.J. and J.R. Pierce, 2010. New evidence on measuring financial constraints: Moving beyond the KZ index. The Review of Financial Studies, 23(5): 1909-1940.Available at: https://doi.org/10.1093/rfs/hhqoo9.

Haider, Z.A., M. Liu, W. Y. and Y. Zhang, 2017. Government ownership, financial constraint, corruption, and corporate performance: International evidence. Journal of International Financial Markets, Institutions and Money, 53(1): 76-93.

He, W. and N.A. Kyaw, 2017. Ownership structure and investment decisions of Chinese SOEs. Research in International Business and Finance, 43(1): 48-57.

Jensen, M.C. and W.H. Meckling, 1976. Theory of the firm: Managerial behavior, agency costs and ownership structure. Journal of Financial Economics, 3(4): 305-360.Available at: https://doi.org/10.1016/0304-405x(76)90026-x.

Kaplan, S. and L. Zingales, 1997. Do investment-cash flow sensitivities provide useful measures of financing constraints? Quarterly Journal of Economics, 112(1): 169-2 15.Available at: https://doi.org/10.1 162/003355397555163.

Kolasa, M., M. Rubaszek and D. Taglioni, 2010. Firms in the great global recession: The role of foreign ownership and financial dependence. Emerging Markets Review, 1 1(4): 341-357.Available at: https://doi.org/10.1016/j.ememar.2010.06.001.

Koo, J. and K. Maeng, 2006. Foreign ownership and investment: Evidence from Korea. Applied Economics, 38(20): 24052414.Available at: https://doi.org/10.1080/00036840500427817.

La Porta, R., F. Lopez-De-Silanes and A. Shleifer, 1999. Corporate ownership around the world. The Journal of Finance, 54(2): 471-517.

Laeven, L., 2002. Financial constraints on investments and credit policy in Korea. Journal of Asian Economics, 13(2): 251269.Available at: https://doi.org/10.1016/s1049-0078(02)00111-2.

Lamont, O., C. Polk and J. Saaá-Requejo, 2001. Financial constraints and stock returns. The Review of Financial Studies, 14(2): 529-554.

Liang, H., B. Ren and S.L. Sun, 2015. An anatomy of state control in the globalization of state-owned enterprises. Journal of International Business Studies, 46(2): 223-240.Available at: https://doi.org/10.1057/jibs.2014.35.

Lin, H.-C.M. and H. Bo, 2012. State-ownership and financial constraints on investment of Chinese-listed firms: New evidence. The European Journal of Finance, 18(6): 497-513.Available at: https://doi.org/10.1080/1351847x.2011.611523.

Mertzanis, C., 2017. Ownership structure and access to finance in developing countries. Applied Economics, 49(32): 31953213.Available at: https://doi.org/10.1080/00036846.2016.1257106.

Meyer, J.R. and E. Kuh, 1957. The investment decision of firms: An empirical study. Cambridge: Harvard University Press.

Modigliani, F. and M.H. Miller, 1958. The cost of capital, corporation finance and the theory of investment. The American Economic Review, 48(3): 261-297.

Mulier, K., K. Schoors and B. Merlevede, 2016. Investment-cash flow sensitivity and financial constraints: Evidence from unquoted European SMEs. Journal of Banking \& Finance, 73: 182-197.Available at: https://doi.org/10.1016/j.jbankfin.2016.09.002.

Myers, S.C. and N.S. Majluf, 1984. Corporate financing and investment decisions when firms have information that investors do not have. Journal of Financial Economics, 13(2): 187-22 1.Available at: https://doi.org/10.1016/0304-405x(84)90023o.

Mykhayliv, D. and K.G. Zauner, 2013. Investment behavior and ownership structures in Ukraine: Soft budget constraints, government ownership and private benefits of control. Journal of Comparative Economics, 41(1): 265-278.Available at: https://doi.org/10.1016/j.jce.2012.03.001. 
Mykhayliv, D. and K. Zauner, 2017. The impact of equity ownership groups on investment: Evidence from Ukraine. Economic Modelling, 64(C): 20-25.Available at: https://doi.org/10.1016/j.econmod.2017.03.005.

O'Toole, C. and C. Newman, 2012. Investment financing and financial development: Firm level evidence from Vietnam. The Institute for International Integration Studies Discussion Paper Series IIISDP, 409: 1-68.

OECD, 1999. OECD principles of corporate governance. Paris: OECD Publishing. Available from https://doi.org/10.1787/9789264173705-en.

Stiglitz, J.E. and A. Weiss, 1981. Credit rationing in markets with imperfect information. The American Economic Review, $71(3): 393-410$.

Tobin, J., 1969. A general equilibrium approach to monetary theory. Journal of Money, Credit and Banking, 1(1): 1529.Available at: https://doi.org/10.2307/1991374.

Tran, N.H. and C.D. Le, 2017. Financial conditions and corporate investment: Evidence from Vietnam. Pacific Accounting Review, 29(2): 183-203.Available at: https://doi.org/10.1108/par-07-2016-0066.

Van Essen, M., J.H. Van Oosterhout and M. Carney, 2011. Corporate boards and the performance of Asian firms: A metaanalysis. Asia Pacific Journal of Management, 29(4): 873-905.Available at: https://doi.org/10.1007/s 10490-011-92691.

Whited, T. and G. Wu, 2006. Financial constraints risk. Review of Financial Studies, 19(2): 531-559.Available at: https://doi.org/10.1093/rfs/hhjo12.

Witt, M.A. and G. Redding, 2013. Asian business systems: Institutional comparison, clusters and implications for varieties of capitalism and business systems theory. Socio-Economic Review, 11(2): 265-300.Available at: https://doi.org/10.1093/ser/mwtoo2.

Yan, B., Y. Zhang, Y. Shen and J. Han, 2017. Productivity, financial constraints and outward foreign direct investment: Firmlevel evidence. China Economic Review, 47(1): 47-64. 